
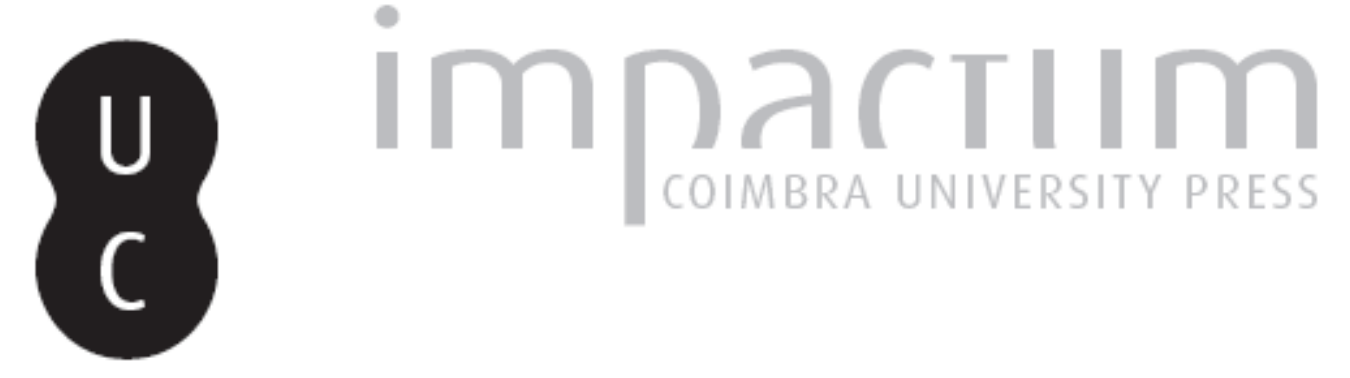

\title{
Erotiká gnorísmata: o reconhecimento do amado em Heliodoro
}

\author{
Autor(es): $\quad$ Duarte, Adriane da Silva
}

Publicado por: Sociedade Brasileira de Estudos Clássicos

URL persistente:

URI:http://hdl.handle.net/10316.2/35801

DOI:

DOI:http://dx.doi.org/10.14195/2176-6436_24_7

Accessed : $\quad$ 26-Apr-2023 02:13:40

A navegação consulta e descarregamento dos títulos inseridos nas Bibliotecas Digitais UC Digitalis, UC Pombalina e UC Impactum, pressupõem a aceitação plena e sem reservas dos Termos e Condições de Uso destas Bibliotecas Digitais, disponíveis em https://digitalis.uc.pt/pt-pt/termos.

Conforme exposto nos referidos Termos e Condições de Uso, o descarregamento de títulos de acesso restrito requer uma licença válida de autorização devendo o utilizador aceder ao(s) documento(s) a partir de um endereço de IP da instituição detentora da supramencionada licença.

Ao utilizador é apenas permitido o descarregamento para uso pessoal, pelo que o emprego do(s) título(s) descarregado(s) para outro fim, designadamente comercial, carece de autorização do respetivo autor ou editor da obra.

Na medida em que todas as obras da UC Digitalis se encontram protegidas pelo Código do Direito de Autor e Direitos Conexos e demais legislação aplicável, toda a cópia, parcial ou total, deste documento, nos casos em que é legalmente admitida, deverá conter ou fazer-se acompanhar por este aviso.

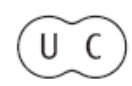




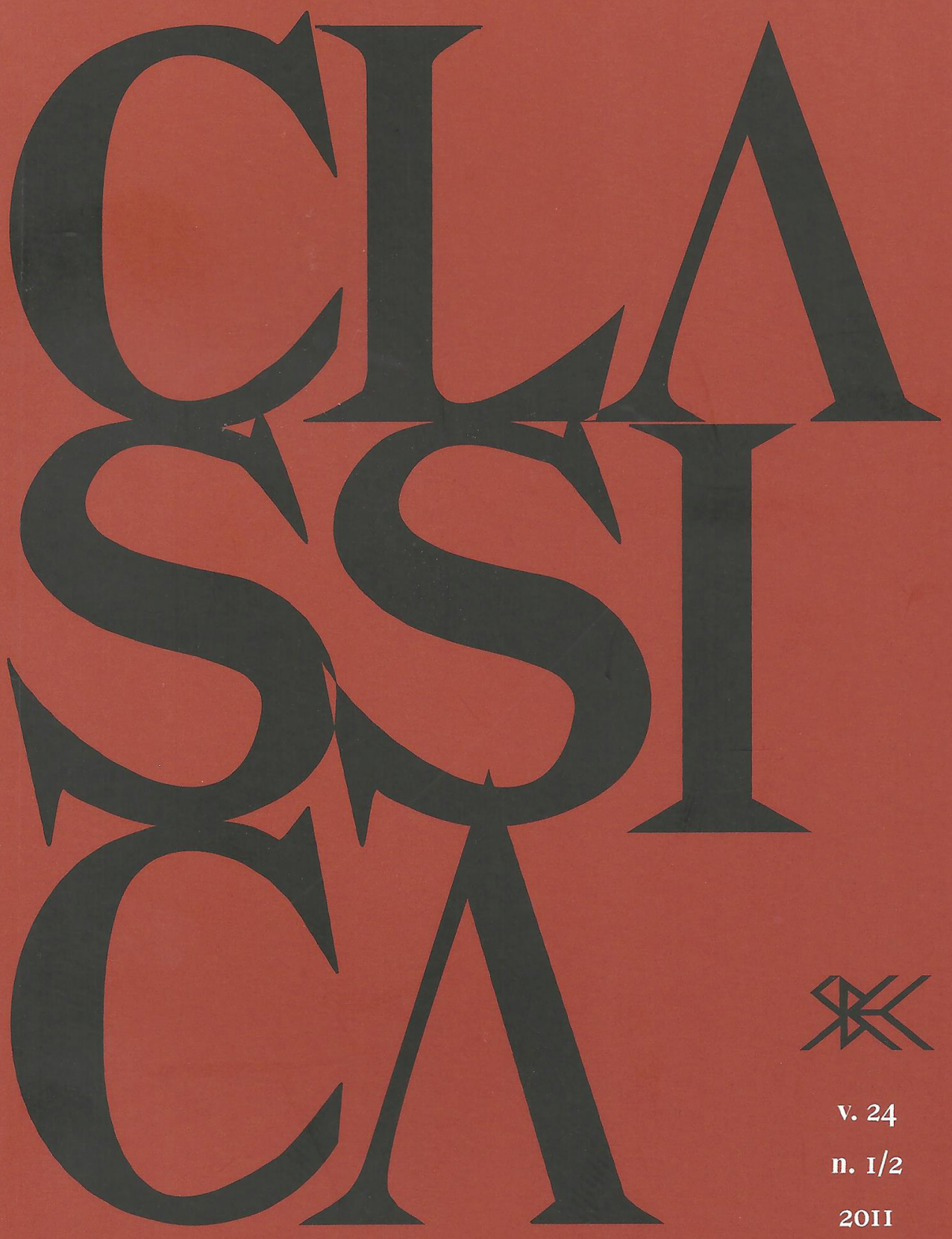




\title{
Erotiká gnorísmata: o reconhecimento do amado em Heliodoro
}

\author{
Adriane da Silva Duarte \\ Universidade de São Paulo \\ Brasil
}

Resumo. As Etiópicas ou Teágenes e Caricleia, de Heliodoro, tem como referência central a Odisseia homérica e, portanto, não poderia deixar de explorar as cenas de reconhecimento. Interessa-me estabelecer como Heliodoro trata o reconhecimento do amado após longa separação. Na Odisseia, Penélope declara a existência de "sinais secretos" (semata kekrummena, XXIIII, 110) pelos quais ela e Odisseu poderiam se reconhecer. Helena, na tragédia homônima de Eurípides, também alude a symbola que somente ela e Menelau compartilham (v. 291). Em Heliodoro (Etiópicas, V, 5, 1-3), Teágenes propõe a Caricleia que elejam sinais que lhes permitam reconhecerem-se caso venham a se separar. Pretendo examinar como Heliodoro dialoga com a tradição, adaptando o motivo às necessidades de sua narrativa.

Palavras-chave. Romance grego; Heliodoro; As Etiópicas; cenas de reconhecimento; Odisseia; Helena.

As Etiópicas, ou Teágenes e Caricleia, de Heliodoro, como boa parte dos romances gregos, narra as desventuras de jovens apaixonados que antes de gozarem plenamente sua paixão são postos à prova pelo destino, tendo que superar os desígnios contrários de suas famílias, a perseguição de bandidos, guerras, além do assédio de amantes inconformados e lascivos. No fim das provações está a promessa da consumação amorosa, mas até que esta se cumpra a castidade deve ser observada como regra. ${ }^{1}$

A despeito de como seja percebida - seja como valorização e estímulo à legítima união dos casais ou como um obstáculo que deve ser superado para a celebração de Eros, em torno do qual é construída a expectativa do romance, e cujas constantes ameaças tornam picante a narrativa-, a castidade dos protagonistas (e parece que só a deles) é regra no romance

\section{E-mail: asduarte@usp.br}

Faculdade de Filosofia, Letras e Ciências Humanas

${ }^{1}$ Uma primeira versão deste texto foi apresentada originalmente como comunicação no XVIII Congresso Nacional de Estudos Clássicos (outubro, 2011, Rio de Janeiro). 
grego. Regra de ouro no caso das moças, que a defendem dos inúmeros ataques de piratas, bandoleiros e predadores de todo tipo, a ponto de beirar o inacreditável que a tenham preservado. ${ }^{2}$ Regra de prata no caso dos rapazes, a quem se tolera eventuais e bem justificadas escapadelas. ${ }^{3}$

O admirável não é que aos homens se conceda maior liberdade sexual, mas o contrário, que sejam tão obstinados no cumprimento dos votos que fizeram a suas amadas. Nas Etiópicas (X, 9), causa assombro à população etíope, reunida para o grande festival nacional, que Teágenes, tão jovem e belo, desconheça os prazeres de Afrodite. Essa perseverança não implica só a determinação de manter-se casto, mas resistência a toda sorte de torturas impingidas pelos que por eles se apaixonam - mulheres e homens igualmente.

A valorização da castidade masculina se dá, ao meu ver, principalmente pelo fato de as uniões narradas nos romances não serem impostas socialmente, como era de costume. Os jovens protagonistas se apaixonam à primeira vista, muitas vezes por desígnio de Eros, que os pune por seu desprezo aos dons de Afrodite e, muitas vezes, contrariam os planos que suas famílias traçaram para eles. ${ }^{4}$ A paixão, quer eletiva, quer fruto da ação divina, explica a razão de os casais manterem-se fiéis e castos até a consumação do casamento.

A castidade das moças é tradicional e sempre foi, na sociedade patriarcal, o pilar do casamento, constituindo a garantia de que os herdeiros são legítimos. Sobre isso não deve pairar dúvidas, ainda mais que as jovens se aventuram para longe da proteção paterna e carecem de guardiões e, portanto, de garantidores de sua virtude. Daí os testes a que algumas

${ }^{2}$ Calírroe, heroína de Cariton de Afrodisia (Quéreas e Calírroe), constitui a exceção à regra ao contrair segundas núpcias quando seu marido ainda vivia. No entanto, diga-se em sua defesa, ela, além de não ser mais virgem, julgava morto o esposo e desejava preservar a vida do filho que esperava dele, fazendo com que o segundo marido o criasse como seu. Para mais detalhes sobre as convenções sexuais no período, cf. Morales, H. Sexuality. In Whitmarsh, T. (ed) The Cambridge Companion to the Greek Novel. Cambridge: Cambridge University Press, 2008, 39-55.

${ }^{3}$ Nos cinco principais romances do corpus, apenas Dafnis (Dafnis e Cloé, de Longo) e Clitofonte (Leucipe e Clitofonte, de Aquiles Tácio) sucumbem à tentação. O primeiro, em sua inocência, recebe aulas práticas de uma vizinha experiente para ensinar as lições a sua amada Cloé depois do casamento, é claro. O segundo, após negar-se a consumar no leito a união legal com Melito, fiel à memória de Leucipe, que julgava morta, cede-lhe por piedade uma única noite de amor, mas esconde o fato de sua amada e dos demais.

${ }^{4}$ Clitofonte (Leucipe e Clitofonte, de Aquiles Tácio) estava prometido a sua meio-irmã; Quéreas era desafeto da família de Calirroé (Quéreas e Calirroé, de Cariton de Afrodisia), Caricleia fora destinada pelo pai adotivo ao sacerdócio em Delfos, cuja virgindade era pré-requisito. 
heroínas têm que se submeter para prová-la. ${ }^{5}$

Sobre essas jovens, que empreendem a fuga em companhia de seus amados, paira o risco e a suspeita. Há, no entanto, duas testemunhas de sua virtude: em primeiro lugar, o leitor, que as sabe castas apesar dos inúmeros ataques a sua honra; em segundo, os amados, que sofrem com elas a interdição aos prazeres amorosos. Mas se o primeiro é constante, o segundo nem sempre está ao seu lado, pois separações do par amoroso em meio à jornada fazem parte da convenção do gênero. É de uma dessas separações, e de sua subsequente reunião, que quero tratar.

A abertura d'As Etiópicas dá-se in media res, em pleno desenvolvimento da ação, constituindo um dos vários aspectos que a remetem a Odisseia. O romance, como se sabe, é um gênero alusivo e sua recepção privilegia a sua relação com outros gêneros, sobretudo a épica. Os protagonistas, após empreender fuga de Delfos, onde Caricleia era sacerdotisa, chegam ao Egito e são capturados por bandoleiros.

Após novo revés, em que os bandidos são atacados por um bando rival, os heróis refugiam-se na caverna onde eram armazenados os produtos do roubo. Deixados a sós, os jovens se entregam à paixão, a ponto do narrador anotar que "seus corpos tornaram-se um só corpo" (V, 4.5:

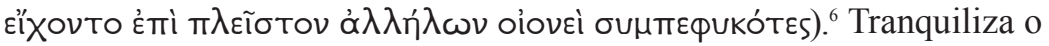
leitor, no entanto, ao assegurar que este "era um amor casto, feito de

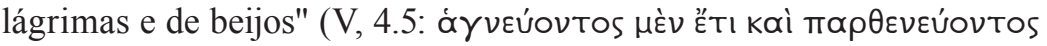

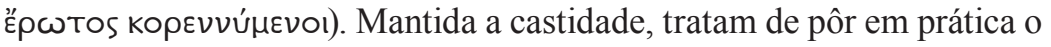
plano de fuga. Devem deixar a caverna para encontrar um companheiro de viagem e infortúnio na cidade de Quéris. Temendo outras guinadas da sorte, Teágenes propõe que acordem sinais entre eles, que permitam reencontrarem-se caso venham a se separar $(\mathrm{V}, 4.7)$ :

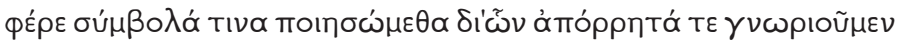

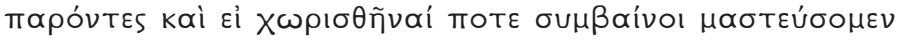
$\dot{\alpha} \lambda \lambda \dot{n} \lambda$ ous.

Vamos, concebamos sinais através dos quais, juntos, nos entenderí-

\footnotetext{
${ }^{5}$ Leucipe deve passar pelo teste de Pã, consentindo ser encerrada em uma gruta dedicada ao deus e aguardar pelo soar mágico da siringe, atestado de sua pureza - em caso de silêncio seria abandonada à morte (Leucipe e Clitofonte, de Aquiles Tácio); Caricleia passa pela prova de fogo etíope em que é instada a caminhar por uma grelha de ouro em brasa que poupa das terríveis queimaduras os virgens (As Etiópicas, de Heliodoro, X, 8). ${ }^{6}$ As traduções de Heliodoro são de minha autoria a partir do texto estabelecido por R. M. Rattenbury e T. W. Lumb para a Belles-Lettres. Cf. Heliodore. Les Éthiopiques (Théagène et Chariclée). Paris: Les Belles Lettres, 1960.
} 
amos sem palavras, e, se acontecer de nos separarmos, buscaríamos um ao outro.

Sendo assim, eles decidem, em caso de separação, inscrever o codinome Pítio(a) nos templos e colunas (hermai) por onde passarem indicando a data e o caminho que tomaram. Em caso de reencontro, a visão do outro bastaria, pois "tempo algum apagaria os sinais do reconheci-

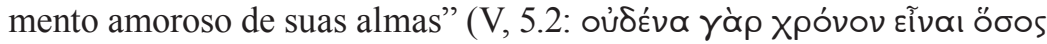

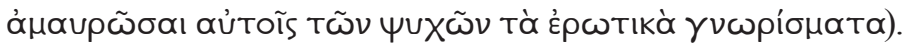

Contudo, como garantia, estabelecem também sinais mais convencionais que levassem ao reconhecimento inconteste: o anel paterno com que Caricleia fora exposta (também usado mais tarde para provar a identidade da heroína a seus pais) e a cicatriz que um javali deixara no

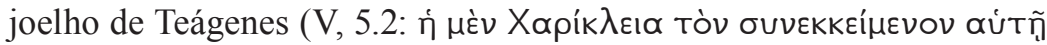

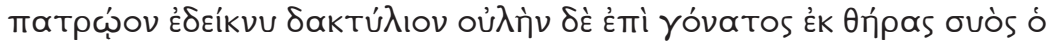

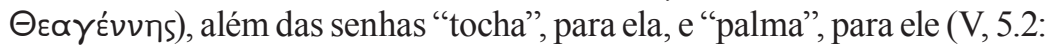

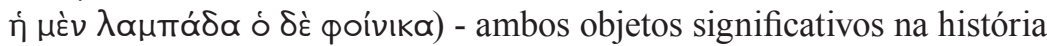

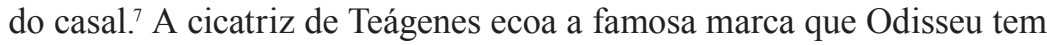
na coxa, pela qual é reconhecido por Euricleia e por Eumeu ao retornar a Ítaca (Odisseia, XIX, 307-507; XXI, 188-244).

Esse excesso de sinais tem por efeito criar no leitor a expectativa pela separação do casal, convencional no gênero, como apontado antes, e seu posterior reencontro. E ela, de fato, não tarda a acontecer. Assim que deixam a caverna, Teágenes e Caricleia são capturados por outro bando armado, soldados de Orodantes, sátrapa do Grande Rei no Egito, e separados: ela é entregue a Nausicles, um mercador egípcio, seguindo para Quéris, e ele é enviado ao general, em Menfis.

Está armada, então, uma situação narrativa em que o leitor é convidado a ler a separação do casal como parelha a de Odisseu e Penélope na Odisseia, não apenas pela referência à cicatriz, que aproxima os heróis, mas pelos sinais combinados em segredo remeterem à declaração de Penélope de que ela e o marido partilhavam códigos pelos quais poderiam se reconhecer (Od. XXIII, 109-110). Essa referência se reforça quando, mais adiante, Caricleia reencontra seu tutor e, libertada pelo mercador, sai em busca de seu amado, cuidando antes de disfarçar-se, a maneira do mesmo Odisseu, de mendigo (Etiópicas, VI, 10). ${ }^{8}$

${ }^{7}$ Caricleia segurava esses objetos quando Teágenes se apresentou para disputar a corrida nos jogos píticos, recebendo, das mãos de sua amada, a palma da vitória (Etiópicas, IV, 1 e 4).

${ }^{8} \mathrm{O}$ papel do herói homérico é partilhado entre Teágenes, Caricleia e Calasiris, conforme 
$\mathrm{Na}$ Odisseia, a mera visão de Odisseu não é capaz de persuadir Penélope. Por mais que o examine, ela não é capaz de reconhecê-lo (Od.

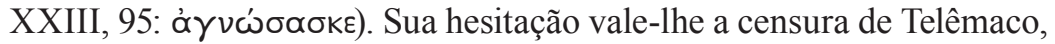
para quem ela tem "o coração mais duro que uma pedra" (Od. XXIII, 103), pois evita o marido recém-chegado em casa. Mas a rainha, imperturbável, declara (Od. XXIII, 107-110)'

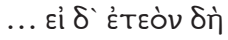

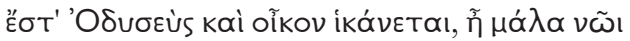

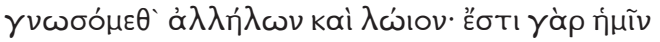

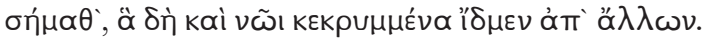
[...] Mas se ele é Odisseu, que, de fato,
ora regressa, possível, decerto, há de ser a nós ambos
reconhecermo-nos logo, pois temos sinais eloqüentes,
de nós sabidos, e a todas as outras pessoas estranhos.

No canto XIX, Penélope oferecera banho e leito para o estrangeiro, considerado com isso seu hóspede. Agora no XXIIII, reivindicando não mais a condição de hóspede, mas a de senhor da casa, $k y ́ r i o s$, Odisseu se banha e ordena que Euricleia lhe prepare o leito - não um leito qualquer

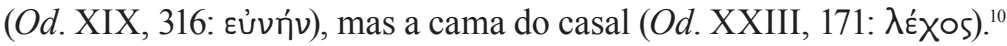

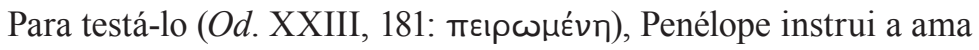
a preparar a cama, mas fora do quarto. Odisseu não pode admitir a possibilidade de o seu leito ter sido removido, e isso por uma simples razão. Ele próprio o construíra a partir do tronco de uma oliveira enraizada no solo, em torno da qual erguera o quarto do casal.

Não escapou a vários comentadores que a imobilidade da cama remete à permanência do relacionamento e à solidez do casamento de Odisseu e Penélope. ${ }^{11}$ A eventualidade da cama ter sido removida implicaria

demonstra J. Morgan. Cf. Morgan, J.; Harrison, S. Intertextuality. In Whitmarsh, T. (ed) The Cambridge Companion to the Greek Novel. Cambridge: Cambridge University Press, 2008, 236.

${ }^{9}$ Cito a Odisseia na tradução de Carlos Alberto Nunes. Cf. Homero. Odisseia. Rio de Janeiro, Ediouro, 1997. O texto grego segue a edição da Loeb: HomEr. The Odyssey. Edited by Goold, G. P. Cambridge/Massachusetts: Harvard University Press, 1984.

${ }^{10}$ A palavra grega para leito, léchos ( $\lambda \dot{x}$ ○ऽ), tem a mesma raiz do termo usado para indicar

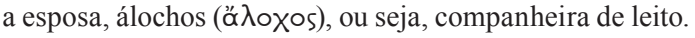

${ }^{11}$ Cf. Murnaghan, S. Disguise and recognition in the Odyssey. Princeton, Princeton University Press, 1984, p. 141; Katz, M. Penelope's renown. Meaning and indeterminacy in the Odyssey, Princeton, Princeton University Press, 1991, p. 178. 
no ingresso de outro homem, um verdadeiro "estranho", ${ }_{12}$ ao quarto do casal e, portanto, seria um indício da traição de Penélope, comprometendo a glória que o herói obtivera com seu retorno e com a vitória sobre os pretendentes. Por isso o leito nupcial e sua integridade constituem o sinal secreto $(O d$. XXIII, 110) a ser compartilhado pelo casal. Odisseu o oferece a Penélope (Od. XXIII, 202-204):

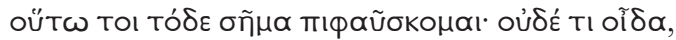

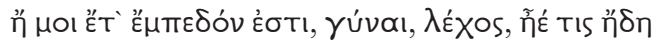

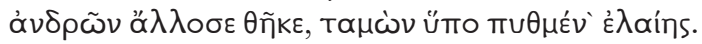

Eis o sinal que me apraz revelar-te. No entanto, ora ignoro se ainda está firme o meu leito no mesmo lugar, ou se acaso tendo cortado bem cerce a oliveira, dali o removeram.

Penélope aceita esse como um sinal "arraigado" ( dade, reconhecendo finalmente Odisseu (Od. XXIII, 205-206):

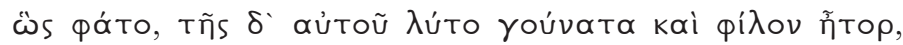

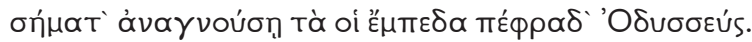

Isso disse ele; abalou-se-lhe o peito, fraquearam-lhe os joelhos, reconhecendo o sinal que Odisseu, tão preciso, dissera. ${ }^{13}$

Voltando às Etiópicas, a existência de sinais secretos entre Caricleia e Teágenes remete a esse passo da Odisseia, em que atestam tanto a identidade do herói quanto a fidelidade e a castidade de Penélope. No caso dos heróis do romance, os sinais são igualmente significativos. Não à toa os codinomes Pítia e Pítio denotam a pureza dos sacerdotes de Ártemis e Apolo, bem como tocha e palma, o culto dessas divindades. Assim a virgindade dos protagonistas é posta em evidência.

Parece-me, no entanto, que o jogo alusivo proposto por Heliodoro é um pouco mais complexo. Se a epopeia é onipresente n' As Etiópicas, a Odisseia em especial, o diálogo com a tragédia fica sugerido já pela moldura que introduz a cena de reconhecimento do casal. A anagnórisis é introduzida pelo vocabulário ligado à performance teatral (VII, 7.4):

${ }^{12}$ Odisseu imediatamente pergunta a Penélope "quem" removeu o leito (Od. XXIII, 184:

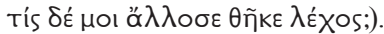

13 "Sinal preciso", na tradução imprecisa de Carlos Alberto Nunes. Minha proposta: "reconhecendo os sinais arraigados que lhe narrara Odisseu". 


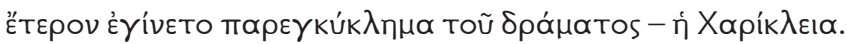

[...] enquanto isso, acontecia uma cena paralela da peça: Caricleia!

A entrada de Caricleia anunciada como nova personagem de um drama e o emprego do termo parenciclema, técnico e raro, alusivo ao enciclema, a plataforma na qual eram mostradas cenas que se passavam no interior das casas na tragédia grega, coloca a anagnórisis sob o signo da tragédia.

De fato, a extraordinária beleza de Caricleia e o cenário de suas aventuras, o Egito, remetem a Helena, de Eurípides. Na tragédia homônima o poeta, ao propor a reunião entre a heroína e seu marido Menelau, após forçada separação, também dialoga com o poema de Homero.

Tal como Caricleia, no começo da tragédia Helena está no Egito, onde é cortejada agressivamente pelo novo rei, Teoclímeno. Menelau, em seu regresso desde Troia, ancora nas proximidades do Palácio em que ela vive, aonde vai buscar ajuda - seu aspecto é miserável, ele apresenta-se coberto de farrapos. Depara-se com sua esposa, mas apesar do que dizem os olhos não pode aceitar-lhe a identidade, pois traz em seu barco o eídolon que os deuses tinham criado à semelhança da mulher e enviado com Páris a Troia, enquanto a verdadeira é confiada ao antigo rei Proteu.

Cria-se, então, um impasse cuja superação demanda uma prova de identidade. De fato, Helena havia dito anteriormente que o reconhecimento entre o casal teria sido possível através de sinais conhecidos por eles

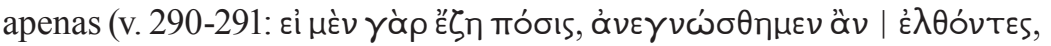

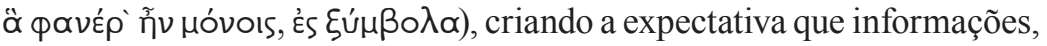
compartilhadas somente pelo casal, levariam ao reconhecimento, como acontece na anagnórisis de Penélope por Odisseu na Odisseia (Od. XXIII, 109-110). ${ }^{14}$

Essa expectativa, no entanto, se frustra. A heroína, ao contrário do que ocorre com a esposa de Odisseu, quando o casal se encontra, não

\footnotetext{
${ }^{14}$ A tragédia de Eurípides, ao desenvolver a versão do mito que defende a castidade de Helena, tenta fazer da heroína uma nova Penélope, dotando-a inclusive de um pretendente, Teoclímeno. No poema homérico, dado o reconhecimento entre os esposos, Penélope justifica sua reticência em acolher Odisseu pelo medo de ser enganada. Como exemplo, cita Helena cujo "feito vergonhoso" deve ser atribuído à instigação de um deus (Od., XXIII,

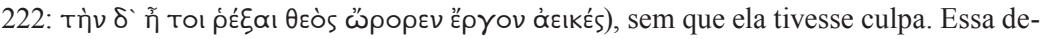
fesa que Penélope faz de Helena pode estar na raiz da referência à heroína na tragédia de Eurípides. As traduções da tragédia são de minha autoria a partir da edição de Kovacs para a Loeb. Cf. EuriPIDES. Helen, Phoenician Women, Orestes. Edited and translated by David Kovacs. Cambridge/Ma: Harvard University Press, 2002.
} 
lança mão de nenhum sinal secreto, o que faz pensar no porque dessa menção. No contexto em que o verso é proferido, Helena ainda não sabe que Menelau ainda vive. Crê, portanto, que seu destino é morrer longe da pátria, no Egito, sem que sua honra seja reabilitada, pois, diz ela, mesmo que algum dia retornasse a Esparta, ninguém acreditaria em sua palavra, pois "Helena, a de Troia, teria partido [i. é, morrido] com Menelau" (v. 288-289) ${ }^{15}$. Mas se vivo estivesse o marido, ele poderia reconhecê-la por

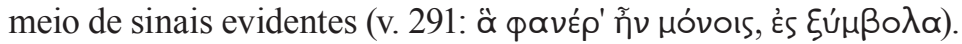

Nesse discurso, a referência a Odisseia é clara, mas talvez não da maneira como comumente é compreendida. É natural, a princípio, pensar que o verso visa à associação entre Helena e Penélope, ressaltando a castidade da filha de Leda, que nunca fora a Troia e nem traira o marido - e, por um lado, isso é verdadeiro. Na Odisseia, o sinal secreto, a solidez da cama do casal, testemunha a fidelidade da esposa durante a ausência do marido. Por analogia pode-se supor, então, que Helena disporia também de um sinal que atestasse a sua castidade. Mas confirmada a morte de Menelau, este sinal de nada valeria, estando ela condenada a ser para sempre a "Helena de Troia", cuja infidelidade foi a causa da morte de tantos heróis.

No entanto, examinando mais de perto o verso, parece que a identificação proposta é entre Helena e Odisseu. Afinal, Helena se imagina retor-

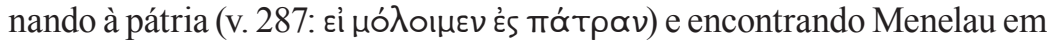
casa. Nessas condições ela seria reconhecida e reabilitada. Ora, na Odisseia, o êxito do retorno do herói depende do reconhecimento de Penélope e da comprovação de sua conduta ilibada em sua ausência, afastando o fantasma de Clitemnestra e da desonra. Helena, ao contrário, reserva para si o papel do herói que retorna e a Menelau o do cônjuge que o espera para validar sua reputação. De fato, todo o episódio do Egito evoca a passagem de Odisseu junto a Calipso e sua percepção que somente conquistaria a glória imperecível se voltasse para Ítaca e para junto dos seus, caso contrário, sofreria a pior das mortes, o esquecimento.

O desenvolvimento da ação trágica confirma essa leitura. Informado por um mensageiro do desvanecimento do eídolon, Menelau parece concluir que não pode retornar de mãos vazias, que sua reputação depende de Helena, como a dela, dele, e o reconhecimento se faz com base na semelhança e na coincidência. Caberá a ela, contudo, desempenhar papel decisivo no planejamento da fuga, em que a métis se sobrepõe à força. É dela a ideia de fingir a morte de Menelau, fazendo-o falso mensageiro

${ }^{15}$ As edições da tragédia trazem, entre cruzes, દ̇ $\lambda \theta \varepsilon \tilde{\nu}$. Schmidt propõe $\theta \alpha v \varepsilon \tilde{v}$. Claro que o primeiro pode ser lido metaforicamente com o mesmo sentido do segundo. 
dessa notícia aos egípcios, e prometer casamento a Teoclímeno desde que possa celebrar no mar ritos fúnebres em memória do marido morto (v. 1050 ss.). Para tal, o casal obteria um barco para a fuga. Também é dela a insistência para que sejam deixadas de lado quaisquer tentativas de enfrentar o inimigo pelas armas, por inócuas dada a desproporção de forças. Essas estratégias são inegavelmente de matriz odisseica.

N'As Etiópicas, a assimilação de Caricleia com Odisseu, evidente em várias passagen ${ }^{16}$, é ressaltada no momento do reconhecimento pelo disfarce de mendigo que ela porta e que impede que Teágenes a reconheça. E, tal qual a Helena euripidiana, ela o identifica imediatamente em meio à multidão reunida às portas de Mênfis, bastando para isso contemplá-lo, pois "o olhar dos amantes é agudo para reconhecer [o amado]"

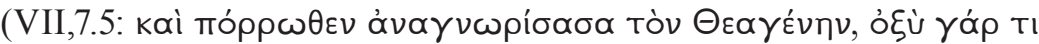

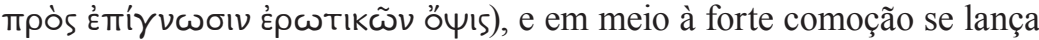
em seus braços. E, como Menelau (v. 566-567) 17 , Teágenes não a reconhece e a repudia - a ponto de afastá-la a tapas. É certo que ela traz o rosto coberto de fuligem e as vestes esfarrapadas, mas o texto parece sugerir que a visão dele, ou seu amor, são mais fracos do que os dela, já que, aos que amam, "o menor movimento ou gesto, mesmo que à distância ou de cos-

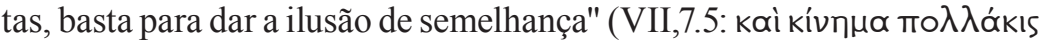

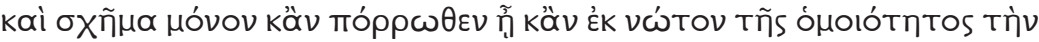

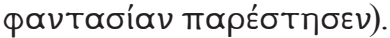

Diante disso, cabe a ela lançar mão dos sinais combinados (VII, 7.7):

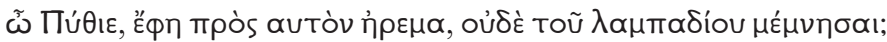

Ó Pítio, diz a ele suavemente, não te recordas da tocha?

Somente ao ouvir os sinais previamente acertados, ele olha para ela de maneira a reconhecê-la - o texto nos diz que ele reconhece os si-

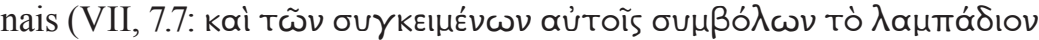

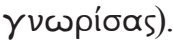

O encontro do casal, nesta que é a mais longa separação que sofrem ao longo do romance, muito embora não seja a última, é fator importante para a consolidação do retorno. Como Menelau e Helena, o encontro acon-

\footnotetext{
${ }^{16}$ Para os paralelos estabelecidos entre os heróis do romance e os de Homero e bibliografia suplementar, cf. Morgan, J.; Harrison, S., 2008: 218-236.

${ }^{17} \mathrm{Cf}$. a cena de reconhecimento em Eurípides, Helena, v. 566: [H.] Ó tu que tardio vens aos

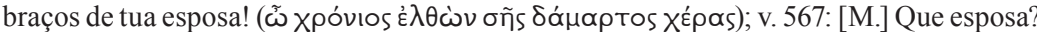

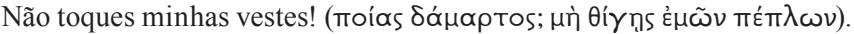


tece no Egito, de modo que os dois juntos possam pavimentar o caminho de volta. Condizente à assimilação da heroína a Odisseu, é para o seu país de origem que eles rumam, a Etiópia, onde ela será reintegrada a sua família após ser reconhecida pelos reis, seus pais. O reconhecimento por parte do amado, então, configura uma etapa necessária para que ocorra o retorno.

Assim, ao compor a sua versão do reconhecimento do amado, Heliodoro sobrepõe em camadas referências ao par Penélope e Odisseu, da Odisseia, e Helena e Menelau, da Helena, provocando, por sua vez, o seu leitor a reconhecer essas alusões literárias e a resgatar a importância da castidade e da astúcia para a união do par amoroso.

TitLe. Erotiká gnorísmata: lovers' recognition in Heliodorus' novel.

Abstract. Heliodorus' An Ethiopian Story (Aethiopica or The Story of Theagenes and Charikleia) connects itself to Homer's Odyssey and explores anagnorisis as a distinct feature. I intend to investigate how Heliodorus develops lovers' recognition after a long separation. Penelope reveals that she and Odysseus have "secret signals" (semata kekrummena, Od., XXIII, 110) by which they can recognize each other. Helen, in Euripides' tragedy, also mentions symbola known only by her and Menelaus (Helen, v. 291). Theagenes (An Ethiopian Story, V, 5, 1-3) suggests to Charikleia that they should pick signals which would help them to recognize one another if set apart. In this paper, I examine how Heliodorus employs literary tradition in benefit of his own work.

KeYwords. Greek novels; Heliodorus; An Ethiopian Story; recognition; Odyssey; Helen. 